\title{
BIOMETRY AND CARCASS CHARACTERISTICS OF LAMBS SUPPLEMENTED IN TROPICAL GRASS PASTURES DURING THE DRY SEASON
}

\author{
BIOMETRIA E CARACTERÍSTICAS DA CARCAÇA DE CORDEIROS \\ SUPLEMENTADOS EM PASTOS DE GRAMÍNEAS TROPICAIS NA ÉPOCA SECA
}

\author{
Thiago Felipe de Medeiros TRINDADE ${ }^{1}$; Gelson dos Santos DIFANTE ${ }^{1^{*}}$; \\ João Virgínio EMERENCIANO NETO² ${ }^{2}$ Leonardo Santana FERNANDES ${ }^{3}$; \\ Itânia Maria Medeiros de ARAÚJO' ${ }^{1}$; Emmanuel Lievio de Lima VÉRAS ${ }^{1}$; \\ Marcone Geraldo COSTA ${ }^{1}$; Maria Gabriela da Trindade SILVA ${ }^{1}$; \\ Mariana Campelo MEDEIROS ${ }^{1}$
}

1. Universidade Federal do Rio Grande do Norte, Unidade Acadêmica Especializada em Ciências Agrárias, Macaíba, RN, Brasil; 2. Universidade Federal do Vale do São Francisco, Campus Ciências Agrárias, Petrolina, PE, Brasil; 3. Universidade Federal do Maranhão, Campus de Chapadinha, Chapadinha, MA, Brasil. * Autor correspondente: gdifante@ hotmail.com

\begin{abstract}
The objective of this study was to evaluate the biometry and carcass characteristics of finished Santa Inês crossbred sheep grazed on tropical grass pastures during the dry season. The study was carried out at the Grupo de Estudos em Forragicultura (GEFOR/UFRN), in Macaíba - RN, Brazil. Four forage treatments were evaluated: Brachiaria brizantha cvs. Marandu e Piatã, Panicum maximum cvs. Aruana e Massai. The 2.88 ha-area used was divided in two blocks of 1.44 ha; each one was composed of four plots corresponding to each cultivar, and each plot was subdivided into six paddocks with an area of 0.06 ha. The pastures were managed under intermittent stocking with seven days of occupation and 35 days of rest, with variable stocking rate. No significant difference was observed in the biometric measurements evaluated in the animals, except for chest width in which animals kept in Marandu pastures obtained higher values than those in the Aruana cultivar. The lowest values of average daily gain, final weight and weight at slaughter values were observed in the animals kept in Aruana cultivars. Cut weights of the shoulder, the loins, short legs/shanks and ribs were higher in the animals kept in Marandu grass and lower in those kept in the Aruana grass; however, no differences were observed for the yield of the cuts and for the biometric measurements of the carcass. The evaluated pasture cultivars did not modify the finished sheep carcasses, however, the lower forage mass from Aruana grass pastures in the dry season affected animal performance and the sheep carcass composition.
\end{abstract}

KEYWORDS: Brachiaria brizantha. Commercial cuts. Panicum maximum. Carcass yield.

\section{INTRODUCTION}

Cutting sheep is an activity that is characterized by the use of available fodder resources to produce quality animal protein, although the meat supply is still irregular in several consumer centers (SOUSA, 2007). The current market demand is for natural products that do not cause damage to health and are produced according to health standards (PIRES et al., 2006). The use of technologies to improve animal performance will indirectly add value to the product if the environmental concept is exploited efficiently (DIFANTE et al., 2014).

Efficiency in sheep meat production can be improved by adopting food systems that ensure superior productivity results to the traditionallydeveloped extensive systems (EMERENCIANO NETO et al., 2011). Thus, cultivating forages responsive to the edaphoclimatic conditions of each region can allow regularization of fodder supply throughout the year. Feed supplementation with grazing concentrates for sheep is intended to mitigate the effects of lower forage quality during periods of drought, a critical period of supply for animals intended for slaughter (ALVES et al., 2013).

The marketing of lambs in most sheep production systems is only based on the observation of animal weight (GARCIA et al., 2003). However, carcass yield assessments and proportions of commercial cuts are important parameters for determining profitability rates in sheep meat production (ALVES et al., 2013). According to Gonzaga Neto et al. (2006), carcass performance and characteristics are directly influenced by the nutritional composition of the animals' diet.

Therefore, the objective of this study was to evaluate the biometry and carcass characteristics of finished Santa Inês crossbred sheep grazed in tropical grass pastures during the dry season. 


\section{MATERIAL AND METHODS}

The study was carried out in the experimental area of the Grupo de Estudos em Forragicultura - (GEFOR), Located at the Jundiaí Agricultural School - Macaíba Campus of the Federal University of Rio Grande do Norte - UFRN, in Macaíba, RN, Brazil. The experimental area has geographical coordinates of latitude $5^{\circ} .89^{\prime} 25.78^{\prime \prime}$ south and longitude $35^{\circ} 36^{\prime} 37.05^{\prime \prime}$ west, at an average altitude of $50 \mathrm{~m}$ above sea level. The experimental period corresponded to 84 days (10/24/2011 to 01/16/2012), characterized as being the dry season in the region.

According to the climatic classification of Thornthwaite (1948), the region has a dry subhumid climate, with water surplus between May and August. Precipitation was $29 \mathrm{~mm}$ during the experimental period (Figure 1), concentrated in the last 15 days of the experiment $(22 \mathrm{~mm})$.

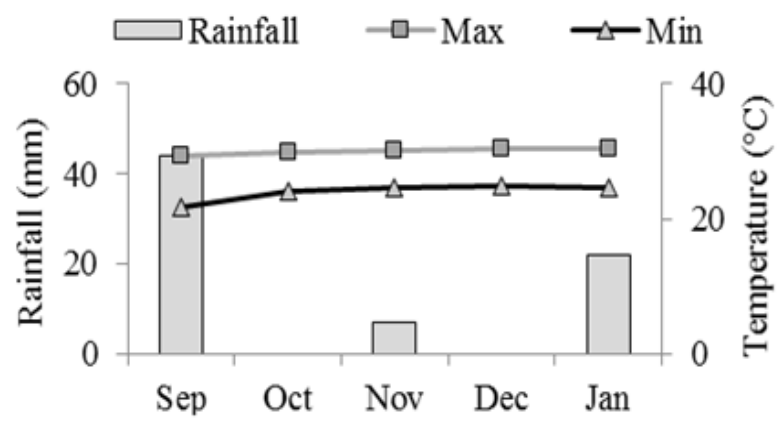

Figure 1. Rainfall, maximum (Max) and minimum (Min) temperature in the experimental area during the evaluations.

The treatments were four tropical forages: Brachiaria brizantha cultivars Marandu and Piatã, and Panicum maximum cultivars Aruana and Massai. The 2.88 ha-area used was divided in two blocks of 1.44 ha; each one was composed of four plots corresponding to each cultivar, and each plot was subdivided into six paddocks with an area of 0.06 ha. The pastures were managed under intermittent stocking with seven days of occupation and 35 days of rest, with variable stocking rate.

Twenty-four (24) whole male Santa-Inês crossbred lambs with a mean initial weight of $23.8 \pm$ $\mathrm{kg}$ were evaluated. Average daily weight gain (g/day) was monitored weekly and calculated by the weight difference from the animals at the beginning and end of the experiment divided by the grazing days. The animals were kept in the pasture during the day (7:30 a.m. to 4:30 p.m.) and taken to a covered sheepfold at night where they were supplemented. Protein supplementation $(39.1 \%$ corn in milled grain, $30.0 \%$ cottonseed cake, $25.1 \%$ soybean meal, $3.0 \%$ mineral supplement and $2.8 \%$ cattle urea) was supplied in the amount of $1.38 \%$ of the $\mathrm{LW}$ concentrate, formulated according to NRC (1985) recommendations for weight gains of 150 g/day. The quantity offered was adjusted weekly according to the weight verified at each weighing. Mean structural, morphological and chemical composition of pastures and concentrate chemical composition are shown in Table 1.

Table 1. Structural condition of the pasture and chemical composition of the concentrate and the available fodder.

\begin{tabular}{llllll}
\hline Variable & Marandu & Aruana & Piatã & Massai & Concentrate \\
\hline Forage mass (kg/ha DM) & 4136.8 & 2390.4 & 3508.0 & 5138.1 & - \\
Leaf:stem ratio & 0.5 & 0.0 & 0.4 & 1.8 & - \\
Green material:dead material ratio & 0.3 & 0.6 & 0.5 & 0.4 & - \\
Crude protein (\%) & 3.2 & 5.2 & 2.7 & 3.6 & 38.7 \\
Neutral Detergent Fiber (\%) & 75.8 & 69.5 & 75.9 & 79.7 & 20.5 \\
Acid Detergent Fiber (\%) & 47.3 & 46.4 & 41.8 & 49.7 & 12.8 \\
Lignin in Acid Detergent (\%) & 9.2 & 9.6 & 7.6 & 10.1 & 2.4 \\
\hline
\end{tabular}

Before slaughter, the animals were weighed to obtain live weight (LW), then they underwent solid fasting for 16 hours, and were then weighed again to measure the slaughter weight (SW) and fasting losses (FL) using the formula, $\mathrm{FL}=\mathrm{LW}$ $\mathrm{LW} / \mathrm{LW}^{*} 100$.

Morphometric in vivo evaluations were performed immediately prior to slaughter with the aid of an anthropometric rule measured according to 
the Spanish model of body length (SPBL): (measured from the tip of the scapula to the tip of the ischium); and the New Zealand model (NZBL): (measured between the base of the neck and the insertion of the tail); rump height, femur height, thorax width, rump width, breast width, thoracic perimeter, thigh perimeter, rump perimeter and leg length.

Lambs were anesthetized by cerebral concussion, and bled by sectioning the carotid artery and jugular vein. After skinning and evisceration, the head and the limbs were removed. Next, the carcasses were weighed to obtain warm carcass weight (WCW) and warm carcass yield (WCY = $\mathrm{WCW} / \mathrm{SW} \times 100$ ). The gastrointestinal content was removed for determining empty body weight (EBW) and biological yield $(\mathrm{BY}=\mathrm{WCW} / \mathrm{EBW} \times 100)$. Subsequently, the carcasses were taken into a cooling chamber for 24 hours at a temperature of $4^{\circ} \mathrm{C}$ to obtain cold carcass weight $(\mathrm{CCW})$, cold carcass yield $(\mathrm{CCY}=\mathrm{CCW} / \mathrm{WS} \times 100)$ and cooling losses (CL).

Morphometric measures evaluated in the carcass were: internal length of the carcass, internal width, perimeter of the thorax, perimeter of the rump, leg length, thigh perimeter, thorax width and rump width. The carcasses were longitudinally divided into two halves, while the left portion was divided into five anatomical regions for weighing and calculating yields, being: short legs/shanks, loins, ribs, shoulders and neck.

The experimental design was in randomized blocks, data were submitted to analysis of variances and the means were compared by Tukey test, adopting a $5 \%$ level of significance. The model used was: Yijk $=\mu+\mathrm{Ci}+\mathrm{Bj}+$ eijk, where: Yijk $=$ Observed value of cultivar $\mathrm{i}$ in block $\mathrm{j}$ in repetition $\mathrm{k} ; \mu=$ general constant (population mean); $\mathrm{Ci}=$ effect of cultivar i, i = Marandu, Aruana, Piatã and Massai; $\mathrm{Bj}=$ effect of block $\mathrm{j}, \mathrm{k}=1,2$; and eijk = random error associated with each Yijk observation.

\section{RESULTS}

Only breast width was affected by the cultivar $(\mathrm{P}<0.05)$ among all the biometric measures evaluated in the animals, animals kept in the Marandu cultivar obtained higher values than those kept in Aruana cultivar (Table 2).

Table 2. Biometric measures in vivo in sheep kept on tropical pastures during the dry season.

\begin{tabular}{llllll}
\hline Variables $(\mathrm{cm})$ & Marandu & Aruana & Piatã & Massai & MSE \\
\hline Body length - Spanish model & $57.17^{\mathrm{a}}$ & $54.83^{\mathrm{a}}$ & $55.58^{\mathrm{a}}$ & $56.33^{\mathrm{a}}$ & 8.02 \\
Body length - New-Zealand model & $63.00^{\mathrm{a}}$ & $62.92^{\mathrm{a}}$ & $63.50^{\mathrm{a}}$ & $63.67^{\mathrm{a}}$ & 7.24 \\
Dorsal height & $67.14^{\mathrm{a}}$ & $61.42^{\mathrm{a}}$ & $63.83^{\mathrm{a}}$ & $62.83^{\mathrm{a}}$ & 6.11 \\
Rump height & $65.75^{\mathrm{a}}$ & $64.42^{\mathrm{a}}$ & $65.33^{\mathrm{a}}$ & $66.17^{\mathrm{a}}$ & 7.19 \\
Femur height & $58.33^{\mathrm{a}}$ & $56.17^{\mathrm{a}}$ & $57.33^{\mathrm{a}}$ & $58.00^{\mathrm{a}}$ & 9.67 \\
Thorax width & $25.50^{\mathrm{a}}$ & $24.50^{\mathrm{a}}$ & $25.17^{\mathrm{a}}$ & $25.17^{\mathrm{a}}$ & 2.72 \\
Rump width & $15.41^{\mathrm{a}}$ & $14.58^{\mathrm{a}}$ & $15.00^{\mathrm{a}}$ & $15.00^{\mathrm{a}}$ & 0.80 \\
Chest width & $18.75^{\mathrm{a}}$ & $16.82^{\mathrm{b}}$ & $17.50^{\mathrm{ab}}$ & $17.08^{\mathrm{ab}}$ & 1.07 \\
Thoracic perimeter & $82.17^{\mathrm{a}}$ & $75.17^{\mathrm{a}}$ & $83.92^{\mathrm{a}}$ & $81.83^{\mathrm{a}}$ & 38.93 \\
Thigh perimeter & $37.33^{\mathrm{a}}$ & $35.33^{\mathrm{a}}$ & $35.50^{\mathrm{a}}$ & $35.00^{\mathrm{a}}$ & 4.41 \\
Rump perimeter & $81.42^{\mathrm{a}}$ & $82.33^{\mathrm{a}}$ & $83.75^{\mathrm{a}}$ & $81.08^{\mathrm{a}}$ & 31.98 \\
Leg length & $33.00^{\mathrm{a}}$ & $31.83^{\mathrm{a}}$ & $32.50^{\mathrm{a}}$ & $33.00^{\mathrm{a}}$ & 3.72
\end{tabular}

Means followed by distinct letters differed from one another $(\mathrm{p}<0.05)$ in the Tukey's test.

The lowest values $(\mathrm{P}<0.05)$ for average daily gain, final weight and slaughter weight were observed in the animals kept in Aruana (Table 3), no differences were observed between the animals kept in the other cultivars.

Empty body, hot and cold carcass weights reflected slaughter weight, with lower weights observed in the animals kept in Aruana grass pastures $(\mathrm{P}>0.05)$. The cold carcass yield of the sheep did not differ according to the cultivars ( $P>0.05)$. Fasting and cooling losses did not differ between the animals kept in the different forage cultivars $(\mathrm{P}>0.05)$, with mean values of 9.0 and
$4.4 \%$, respectively. The highest biological yield was observed in the animals kept in the Marandu cultivar $(\mathrm{P}<0.05)$.

A difference in the shoulder, loins, short legs/shanks and rib weights was observed according to the cultivars $(\mathrm{P}<0.05)$, with the highest values observed in the animals kept in Marandu grass, the lowest values for animals kept in Aruana grass (Table 4), and intermediate values for these cuts were observed in the animals kept in Piatã and Massai grasses. Neck weight did not differ according to cultivar $(\mathrm{P}>0.05)$. 
Table 3. Average yield characteristics of Santa Inês crossbred sheep carcass supplemented on tropical pastures during the dry season

\begin{tabular}{llllll}
\hline Variables & Marandu & Aruana & Piatã & Massai & EPM \\
\hline Average daily gain (g/day) & $133.7^{\mathrm{a}}$ & $81.1^{\mathrm{b}}$ & $142.20^{\mathrm{a}}$ & $122.4^{\mathrm{a}}$ & 82.36 \\
Final weight $(\mathrm{kg})$ & $37.90^{\mathrm{a}}$ & $33.41^{\mathrm{b}}$ & $36.18^{\mathrm{a}}$ & $36.35^{\mathrm{a}}$ & 2.82 \\
Weight at slaughter $(\mathrm{kg})$ & $34.62^{\mathrm{a}}$ & $30.37^{\mathrm{b}}$ & $32.87^{\mathrm{a}}$ & $33.05^{\mathrm{a}}$ & 0.79 \\
Empty body weight $(\mathrm{kg})$ & $27.40^{\mathrm{a}}$ & $24.85^{\mathrm{b}}$ & $27.25^{\mathrm{a}}$ & $28.51^{\mathrm{a}}$ & 2.14 \\
Hot carcass weight $(\mathrm{kg})$ & $14.91^{\mathrm{a}}$ & $12.03^{\mathrm{b}}$ & $14.06^{\mathrm{a}}$ & $13.73^{\mathrm{a}}$ & 0.84 \\
Cold carcass weight $(\mathrm{kg})$ & $14.24^{\mathrm{a}}$ & $11.57^{\mathrm{b}}$ & $13.39^{\mathrm{a}}$ & $13.07^{\mathrm{a}}$ & 0.73 \\
Biological yield $(\%)$ & $54.38^{\mathrm{a}}$ & $48.39^{\mathrm{b}}$ & $49.47^{\mathrm{b}}$ & $48.15^{\mathrm{b}}$ & 23.13 \\
Hot carcass yield $(\%)$ & $41.13^{\mathrm{a}}$ & $38.10^{\mathrm{a}}$ & $40.74^{\mathrm{a}}$ & $39.55^{\mathrm{a}}$ & 4.21 \\
\hline
\end{tabular}

Means followed by distinct letters differed from one another $(\mathrm{P}<0.05)$ in the Tukey's test.

Table 4. Weight and yield of commercial sheep cuts in tropical pastures.

\begin{tabular}{llllll}
\hline Variables & Marandu & Aruana & Piatã & Massai & MSE \\
\hline Shoulder (kg) & $1.30^{\mathrm{a}}$ & $1.01^{\mathrm{b}}$ & $1.17^{\mathrm{ab}}$ & $1.10^{\mathrm{ab}}$ & 0.01 \\
Neck (kg) & $0.76^{\mathrm{a}}$ & $0.74^{\mathrm{a}}$ & $0.75^{\mathrm{a}}$ & $0.74^{\mathrm{a}}$ & 0.02 \\
Loin (kg) & $0.94^{\mathrm{a}}$ & $0.72^{\mathrm{b}}$ & $0.87^{\mathrm{ab}}$ & $0.81^{\mathrm{ab}}$ & 0.01 \\
Short legs/shanks (kg) & $2.27^{\mathrm{a}}$ & $1.85^{\mathrm{c}}$ & $2.13^{\mathrm{ab}}$ & $2.04^{\mathrm{bc}}$ & 0.02 \\
Ribs (kg) & $1.79^{\mathrm{a}}$ & $1.46^{\mathrm{b}}$ & $1.71^{\mathrm{ab}}$ & $1.71^{\mathrm{ab}}$ & 0.03 \\
\hline Yields (\%) & & & & \\
\hline Shoulder & $18.29^{\mathrm{a}}$ & $17.71^{\mathrm{a}}$ & $17.75^{\mathrm{a}}$ & $17.07^{\mathrm{a}}$ & 1.76 \\
Neck & $10.77^{\mathrm{a}}$ & $13.08^{\mathrm{a}}$ & $11.25^{\mathrm{a}}$ & $11.43^{\mathrm{a}}$ & 5.13 \\
Loin & $13.35^{\mathrm{a}}$ & $12.55^{\mathrm{a}}$ & $13.05^{\mathrm{a}}$ & $12.57^{\mathrm{a}}$ & 1.59 \\
Short legs/shanks & $32.11^{\mathrm{a}}$ & $32.60^{\mathrm{a}}$ & $32.07^{\mathrm{a}}$ & $31.64^{\mathrm{a}}$ & 1.90 \\
Ribs & $24.40^{\mathrm{a}}$ & $25.51^{\mathrm{a}}$ & $25.82^{\mathrm{a}}$ & $26.55^{\mathrm{a}}$ & 3.71 \\
\hline
\end{tabular}

Means followed by distinct letters differed from one another in the Tukey's test $(\mathrm{p}<0.05)$.

The cut yields did not differ according to the cultivars $(\mathrm{P}>0.05)$, with mean carcass values of $17.7 ; 11.6 ; 12.9 ; 32.1$ and $25.6 \%$ for shoulder, neck, loins, short legs/shanks and ribs, respectively.

Forage cultivars did not affect the biometric measurements of lamb carcass $(\mathrm{P}>0.05)$, with mean values of $65.3 ; 27.7 ; 69.6 ; 57.8 ; 35.2 ; 31.9 ; 22.1$ and $15.8 \mathrm{~cm}$ for internal length, internal width, thorax perimeter, rump perimeter, leg length, thigh perimeter, thorax width and rump width of the carcass, respectively.

The most important correlations (Table 5) were: chest width, which had high to moderate correlations with the weights of all cuts, except neck and ribs weight. Thoracic perimeter had a moderate correlation with the ribs weight.

Table 5. Correlation coefficients between biometric measures and the weights of commercial cuts in Santa Inês crossbred sheep supplemented in tropical pastures.

\begin{tabular}{lllllll}
\hline Measurement & WHC & SHW & NKW & LOW & SHW & RBW \\
\hline Body length - Spanish model & $0.50^{*}$ & $0.17^{\text {ns }}$ & $0.25^{\text {ns }}$ & $0.53^{*}$ & $0.43^{*}$ & $0.48^{*}$ \\
Body length - New-Zealand model & $0.28^{\text {ns }}$ & $0.03^{\text {ns }}$ & $0.38^{\text {ns }}$ & $0.24^{\text {ns }}$ & $0.21^{\text {ns }}$ & $0.13^{\text {ns }}$ \\
Dorsal height & $0.40^{*}$ & $0.26^{\text {ns }}$ & $-0.02^{\text {ns }}$ & $0.40^{*}$ & $0.36^{\text {ns }}$ & $0.42^{*}$ \\
Rump height & $0.30^{\text {ns }}$ & $0.24^{\text {ns }}$ & $-0.28^{\text {ns }}$ & $0.38^{\text {ns }}$ & $0.24^{\text {ns }}$ & $0.41^{*}$ \\
Femur height & $0.52^{*}$ & $0.33^{\text {ns }}$ & $-0.13^{\text {ns }}$ & $0.47^{*}$ & $0.44^{*}$ & $0.60^{*}$ \\
Thorax width & $0.18^{\text {ns }}$ & $0.05^{\text {ns }}$ & $0.06^{\text {ns }}$ & $0.04^{\text {ns }}$ & $0.24^{\text {ns }}$ & $0.35^{\text {ns }}$ \\
Rump width & $0.41^{*}$ & $0.19^{\text {ns }}$ & $0.16^{\text {ns }}$ & $0.47^{*}$ & $0.34^{\text {ns }}$ & $0.36^{\text {ns }}$ \\
Chest width & $0.67^{*}$ & $0.75^{*}$ & $0.20^{\text {ns }}$ & $0.50^{*}$ & $0.69^{*}$ & $0.37^{\text {ns }}$ \\
Thoracic perimeter & $0.37^{\text {ns }}$ & $0.10^{\text {ns }}$ & $-0.16^{\text {ns }}$ & $0.45^{*}$ & $0.20^{\text {ns }}$ & $0.68^{*}$ \\
Thigh perimeter & $0.38^{\text {ns }}$ & $0.45^{*}$ & $0.11^{\text {ns }}$ & $0.30^{\text {ns }}$ & $0.41^{*}$ & $0.11^{\text {ns }}$ \\
Rump perimeter & $0.23^{\text {ns }}$ & $0.26^{\text {ns }}$ & $-0.03^{\text {ns }}$ & $0.15^{\text {ns }}$ & $0.25^{\text {ns }}$ & $0.11^{\text {ns }}$ \\
\hline
\end{tabular}

WHC, half-carcass weight; SHW, shoulder weight; NKW, neck weight; LOW, loin weight; SHW, short legs/shanks weight; RBW, ribs weight. Ns, not significant, * Significant at $5 \%$. 


\section{DISCUSSION}

According to Maciel et al. (2015), the lack of variation observed among length, perimeter, depth and width measures of the carcasses may occur when there is similarity in carcass weights and yields of meat cuts (Table 4).

The lower daily gain observed in the animals kept in Aruana grass pastures can be attributed to lower forage and leaf blade mass in the pastures of this cultivar (Table 1), which possibly led to a reduced intake of nutrients by the animals, and consequently, reduced muscular deposition. Final weight is a function of the average daily gain and the time required for reaching the defined slaughter weight; when there is an increase in slaughter weight and consequent carcass weight, there is also an increase of muscles (LAWRIE, 1998). In this study, the animals required 80 days on average to reach the desirable conformation with the purpose of obtaining the best development in the cuts.

According to Landim et al. (2007), empty body weight has a high correlation with hot and cold carcass weight, and they recommend that live weight can be used as an indicator for carcass weight. Although warm carcass weight in the animals kept in Aruana grass pastures was lower than the others, it was higher than those observed by Menezes et al. (2008) in finished Santa Inês lambs kept in tropical forage pasture, receiving 300 g/animal/day of concentrate. The authors emphasize that the use of tropical forages associated with concentrate supplementation during the dry season enables satisfactory results in lamb carcass weight.

The values obtained for cooling loss were higher than the $2.5 \%$ reported by Castro et al. (2017) for Santa Inês sheep, but considered satisfactory since according to Sañudo et al. (1986), cooling weight losses between 3 and $4 \%$ are acceptable for sheep meat breeds, which occur due to moisture losses and chemical reactions that occur in the muscle.

Although differences in warm carcass weights were observed, cold carcass yield did not differ according to the cultivars, since lighter cold carcasses were also from lighter animals at slaughter, with an cold carcass yield average of $39.9 \%$. Higher carcass yields are directly related to the amount of concentrate supplement available to lambs (CARVALHO et al., 2005).
A higher carcass weight of animals kept in Marandu grass pastures when compared to those kept in Aruana grass pastures also resulted in greater weight of the shoulders, loins, short legs/shanks and ribs (Table 3); according to Urbano et al. (2015), there is a direct dependence relation between the weight of cuts and the carcass weight, where the higher the carcass weight, the greater the weight of the cuts, and the reverse is also true.

According to Rosa et al. (2002), bone and muscle growth in the neck happens early; therefore, the animal's neck was already completely formed in the termination phase, and the variation could only occur as a result of fat deposition, which did not occur since there was no variation in the concentrate amount supplied to the animals kept in the different cultivars.

The weights obtained for the commercial cuts were higher than those described by Oliveira et al. (2014) for finished $1 / 2$ blood Santa Inês sheep kept in confinement, showing that finishing sheep supplemented with concentrate in pastures may be a good substitute for confinement, due to lower demand for labor and facilities.

The similarity between the yields of the cuts can be attributed to the anatomical harmony law, where almost all regions of the body are in similar proportions for carcasses with similar weights (BOCCARD, DUMONT, 1960). This can be confirmed by the complete similarity of these yields to those observed by Cardoso et al. (2016) in Santa Inês sheep kept in confinement, and by Ortiz et al. (2005) in Suffolk lambs (19.9; 9.2; 10.7 and 34.9\% of the carcass for shoulders, neck, loins and short legs/shanks).

The significant correlations found show that the use of these biometric measurements performed on living animals can serve as parameters for predicting the weights of these commercial cuts, and therefore the economic results of slaughter (Table 5). Chest width can be used to predict final live weight at slaughter (ALVES et al., 2003), due to high correlation between chest development and increase in live weight in sheep.

\section{CONCLUSIONS}

The evaluated cultivars did not modify the yields of cuts in sheep carcasses kept in pasture, however the lower forage mass of the Aruana pasture in the dry season compromised the weight of the carcass and its components.

RESUMO: Objetivou-se avaliar a biometria e as características da carcaça de ovinos mestiços de Santa Inês terminados em pastos de gramíneas tropicais na época seca. O trabalho foi realizado no Grupo de Estudos em 
Forragicultura (GEFOR/UFRN), em Macaíba - RN, Brasil. Os tratamentos avaliados foram quatro forrageiras: Brachiaria brizantha cvs. Marandu e Piatã, Panicum maximum cvs. Aruana e Massai. A área utilizada foi de 2,88 ha dividida em dois blocos de 1,44 ha, onde cada um desses foi constituído de quatro parcelas correspondente a cada cultivar, e cada parcela subdivida em seis piquetes com área de 0,06 ha. Os pastos foram manejados sob lotação intermitente com sete dias de ocupação e 35 dias de descanso, com taxa de lotação variável. Não houve diferença significativa nas medidas biométricas avaliadas nos animais, exceto para a largura do peito, em que os animais mantidos nos pastos da cultivar Marandu obtiveram valores maiores que aqueles da cultivar Aruana. Os menores valores de ganho médio diário, peso final e peso ao abate foram observados nos animais mantidos na cultivar Aruana. Os pesos dos cortes paleta, lombo, pernil e costela foram maiores nos animais mantidos no capim-marandu e menores naqueles mantidos no capim-aruana, porém não foram observadas diferenças para o rendimento dos cortes e para as medidas biométricas na carcaça. As cultivares avaliadas não modificam as carcaças de ovinos terminados em pasto, porém a menor massa de forragem dos pastos da cultivar Aruana na época seca comprometem o desempenho animal e a composição das carcaça de ovinos.

PALAVRAS-CHAVE: Brachiaria brizantha. cortes comerciais. Panicum maximum. rendimento de carcaça.

\section{REFERENCES}

ALVES, K. S.; CARVALHO, F. F. R.; VÉRAS, A. S. C.; ANDRADE, M. F.; COSTA, R. G.; BATISTA, A. M. V.; MEDEIROS, A. N.; SOUTO MAIOR JUNIOR, R. J.; ANDRAK. B. Dietary levels of energy for Santa Inês sheep: Performance. Revista Brasileira de Zootecnia, Viçosa, v. 32, n. 6, p. 1937-1944, 2003. http://dx.doi.org/10.1590/S1516-35982003000800018

ALVES, D. D.; ARAÚJO, L. M.; MONTEIRO, H. C. F.; LEONEL, F. P.; SILVA, F. V.; SIMÕES, D. A.; GONÇALVES, W. C.; BRANT, L. M. C. Carcass characteristics, non-carcass components and morphometry in sheep submitted to different supplementation strategies. Semina: Ciências Agrárias, Londrina, v. 34, n. 6, p. 3093-3104, 2013. http://dx.doi.org/10.5433/1679-0359.2013v34n6p3093

BOCCARD, R.; DUMONT, B. L. Etude de la production de la viande chez les ovins. II variation de l'importance relative des differents régions corporelles de l'agneau de boucherie. Annales de Zootechnie, Les Ulis, v. 9, p. 355-365, 1960. https://hal.archives-ouvertes.fr/hal-00886736

CARDOSO, D. B.; VÉRAS, R. M. L; CARVALHO, F. F. R; MAGALHÃES, A. L. R; VASCONCELOS, G. A.; URBANO, S. A.; FONSÊCA, G. M.; FREITAS, M. T. D. Carcass and non-carcass component characteristics of lambs fed with cassava wastewater dregs in replacement of corn. Semina: Ciências Agrárias, Londrina, v. 37, n. 4, p. 2711-2724, 2016. http://dx.doi.org/10.5433/1679-

0359.2016v37n4Sup11p2711

CARVAlHO, S.; VERGUEIRO, A.; KIELING, R.; TEIXEIRA, R. C.; PIVATO, J.; VIERO, R.; CRUZ, A. N. Avaliação da suplementação concentrada em pastagem de Tifton-85 sobre os componentes não carcaça de cordeiros. Ciência Rural, Santa Maria, v. 35, n. 2, p.435-439, 2005. http://dx.doi.org/10.1590/S010384782005000200030

CASTRO, D. P. V.; YAMAMOTO, S. M.; ARAÚJO, G. G. L.; PINHEIRO, R. S. B.; QUEIROZ, M. A. A.; ALBUQUERQUE, I. R. R.; MOURA, J. H. A. Influence of drinking water salinity on carcass characteristics and meat quality of Santa Inês lambs. Tropical Animal Health and Production, v. 49, n. 6, p. 1095-1100, 2017. http://dx.doi.org/10.1007/s11250-017-1289-5

CIRNE, L. G. A.; BARONI, M. R.; OLIVEIRA, G. J. C.; JAEGER, S. M. P. L.; BAGALDO, A. R.; LEITE, M. C. P.; MARQUES, J. A.; CARVALHO, G. G. P. Characteristics of carcass and non-carcass components of lambs supplemented with fodder salt from Gliricidia sepium (Jacq.) Walq. Arquivo Brasileiro de Medicina Veterinária e Zootecia, Belo Horizonte, v. 65, n. 1, p .289-293, 2013. http://dx.doi.org/10.1590/S010209352013000100041 
DIFANTE, G. S.; EUCLIDES, V. P. B.; MONTAGNER, D. B.; FERNANDES, L. S. Inovações tecnológicas no manejo da pastagem e do pastejo frente às perspectivas de mudanças climáticas. In: Anais... 51 Reunião da Sociedade Brasileira de Zootecnia, 2014.

EMERENCIANO NETO, J. V.; PEREIRA, G. F.; MEDEIROS, H. R.; GRACINDO, A. P. A. C.; DIFANTE, G. S. Caracterização e avaliação econômica de sistemas de produção de agricultura familiar no semiárido.

Revista Brasileira de Agropecuária Sustentável, Viçosa, v. 1, n. 1, p. 21-28, 2011.

http://dx.doi.org/10.21206/rbas.v1i1.7

GARCIA, I. F.; PEREZ, J. R. O.; TEXEIRA, J. C. Componentes de carcaça e composição de alguns cortes de cordeiros Texel $\times$ Bergamácia, Textel $\times$ Santa Inês e Santa Inês puros, terminados em confinamento, com casca de café como parte da dieta. Revista Brasileira de Zootecnia, Viçosa, v. 32, n. 6, p. 1999-2006, 2003. http://dx.doi.org/10.1590/S1516-35982003000800025

GONZAGA NETO, S.; SILVA SOBRINHO, A. G.; ZEOLA, N. M. B. L.; MARQUES, C. A. T.; SILVA, A. M. A.; PEREIRA FILHO, J. M.; FERREIRA, A. C. D. Características quantitativas da carcaça de cordeiros deslanados Morada Nova em função da relação volumoso:concentrado na dieta. Revista Brasileira de Zootecnia, Viçosa, v. 35 n. 4, p. 14871495, 2006. http://dx.doi.org/10.1590/S1516-35982006000500031

LANDIM, A. V.; MARIANTE, A. S.; MCMANUS, C. M.; GUGEL, R.; PAIVA, S. R. Características quantitativas da carcaça, medidas morfométricas e suas correlações em diferentes genótipos de ovinos. Ciência Animal Brasileira, Goiânia, v. 8, n. 4, p. 665-676, 2007.

Lawrie, R. A. 1998. Lawrie's meat science, 6th edn. Woodhead Publishing limited. Cambridge, England.

MACIEL, M. V.; CARVALHO, F. F. R.; BATISTA, Â. M. V.; GUIM, A.; SOUZA, E. J. O.; MACIEL, L. P. A. A.; PEREIRA NETO, J. D.; LIMA JUNIOR, D. M. Carcass and non-carcass characteristics of sheep fed on cassava (Manihot pseudoglaziovii Pax \& K. Hoffm.). Chilean journal of agricultural research, Chillán, v. 75, n. 3, p. 307-312, 2015. http://dx.doi.org/10.4067/S0718-58392015000400006

MENEZES, L. F. O.; LOUVANDINI, H.; MARTHA JUNIOR, G. B.; McMANUS, C.; GARCIA, J. A. S.; MURATA, L. S. Características de carcaça, componentes não-carcaça e composição tecidual e química da $12^{a}$ costela de cordeiros Santa Inês terminados em pasto com três gramíneas no período seco. Revista Brasileira de Zootecnia, Viçosa, v. 37, n. 7, p. 1286-1292, 2008. http://dx.doi.org/10.1590/S1516-35982008000700021

NRC-National Research Council. Nutrient requirement of sheep. 6. ed. Washington, D.C.: National Academy Press, 1985.

OLIVEIRA, D. S.; ROGÉRIO, M. C. P.; BATISTA, A. S. M.; ALVES, A. A.; ALBUQUERQUE, F. H. M. A. R.; POMPEU, R. C. F. F.; GUIMARÃES, V. P.; DUARTE, T. F. Desempenho e características de carcaça de cordeiros SPRD cruzados com as raças Santa Inês e Somalis Brasileira terminados em confinamento. Revista Brasileira de Saúde e Produção Animal, Salvador, v. 15, n. 4, p. 937-946, 2014. http://dx.doi.org/10.1590/S1519-99402014000400021

ORTIZ, J. S.; COSTA, C.; GARCIA, C. A.; SILVEIRA, L. C. A. Medidas objetivas das carcaças e composição química do lombo de cordeiros alimentados e terminados com três níveis de proteína bruta em creepfeeding. Revista Brasileira de Zootecnia, Viçosa, v. 34, n. 6, p. 2382-2389, 2005. http://dx.doi.org/10.1590/S151635982005000700026

PIRES, C. C.; CARNEIRO, R. M.; MÜLLER, L.; SOUZA, J. H. S.; CARDOSO, A. R.; PERES NETO, D.; VOLLENHAUPT, L. S. Avaliação da carcaça e componentes do peso vivo, de cordeiros de parto simples desmamados, parto simples não desmamados e de parto duplo desmamados. Revista Brasileira de Agrociência, Pelotas, v. 12, n. 1, p. 93-97, 2006. http://dx.doi.org/10.18539/cast.v12i1.4495 
ROSA, G. T.; PIRES, C. C.; SILVA, J. H. S.; MÜLLER, L. Crescimento de osso, músculo e gordura dos cortes da carcaça de cordeiros e cordeiras em diferentes métodos de alimentação. Revista Brasileira de Zootecnia, Viçosa, v. 31, n. 6, p. 2283-2289, 2002. http://dx.doi.org/10.1590/S0103-84782005000400019

SAÑUDO, C.; SIERRA, I. Calidad de la canal em la especie ovina. Ovino, v.11, n.1, p.127-157, 1986.

SOUSA, W. H. O agronegócio da caprinocultura de corte no Brasil. Revista Tecnologia \& Ciência Agropecuária, João Pessoa, v. 1, n. 1, p. 51-58, 2007.

THORNTHWAITE, C.W. An approach toward a rational classification of climate. Geographical Review, London, v. 38, p. 55-94, 1948. http://dx.doi.org/10.2307/210739

URBANO, S. A.; FERREIRA, M. A.; VÉRAS, R. M. L.; AZEVEDO, P. S.; SANTOS FILHO, H. B.; VASCONCELOS, G. A.; OLIVEIRA, J. P. F. Características de carcaça e composição tecidual de ovinos Santa Inês alimentados com manipueira. Revista Brasileira de Ciências Agrárias, Recife, v. 10, n. 3, p. 466-472, 2015. http://dx.doi.org/10.5039/agraria.v10i3a4812 